\title{
MANAGEMENT OF STAFF FLUCTUATION IN TRANSPORT ENTERPRISES
}

\section{Asya Grigorova Tsonkova ${ }^{1}$}

\begin{abstract}
The dynamic transport business and the ever-growing competition on the market for transport services increase the significance not just of staff management but of effective staff management as well. The staff is an inseparable part of both resources and enterprise structure however, it should be underlined that it is the most complex and most difficult one to manage, plan, organize and control. The main key factor for the success of a transport enterprise is its employees and workers. Given the ever-growing supply of transport services, customer criteria regarding their quality grow as well. European transport firms constantly strive to implement special approaches, principles and methods in the management of human resources with the purpose of improving the quality of the services they offer. However, one of the primary and an especially serious issue related to staff management in transport firms remains staff fluctuation. It is an essential part of financial relations and an indispensable component of the complex PR system. The present report studies the issues related to staff management and fluctuation within transport firms.
\end{abstract}

JEL Classification Number: R49; DOI: http://dx.doi.org/10.12955/cbup.v5.979

Keywords: transport enterprise, transport services, competitiveness, staff management, staff fluctuation

\section{Introduction}

Human resources in a transport enterprise are a structured aggregate of people who possess specific knowledge and skills and respective practical experience through which the enterprise's normal function and the successful execution of tasks is ensured. According to Armstrong (2006), human resources are the most valuable assets that an organization owns and their effective management is the key to its success. Staff management is viewed as a primary part of the management of transport firms, but it is also a relatively independent one, differing from the management of other production resources. The challenge that the successful development of transport organizations faces in terms of strong competition and globalization is the people. The human factor plays an increasingly significant and defining role in regard to the development and success of every modern enterprise. In order to achieve success in an organization, it is essential to take into account the factors that motivate employees to do their best and work more efficiently.

The ability to aim the staff towards successfully achieving preliminarily set goals plays a leading role in staff management. The primary goal of the management is to achieve a sense of community and to ensure harmony between the needs of the transport organization and the necessities of its employees. Staff management is characterized by a series of specific traits, presented in two directions: motivation and defining the worth of human resources (Tzvetkova, 2015).

The mechanisms for increasing transport effectiveness are aimed towards increasing competitiveness, economic growth and creating more and better work places, which is set annually in the yearly strategies of major European firms, primarily the ones from Western Europe. In recent years, business in Bulgaria has also strived towards improving the management and optimizing the fluctuation in transport enterprises. Every transport enterprise builds a concept about its goals, plans and its results. Mostly with the experience of European and global management systems having influence to this concept. For the Bulgarian transport market the strategy for human resource management in the transport sector plays a defining role in its correspondence to the challenge that the Bulgarian government faces - namely, Bulgaria's successful integration in the European Union. Each transport company determines the need for workers by planning and integrating them in the process of production and economic activities. The determination of the need for workers is influenced by various factors, amongst which are: incorporating automated systems for information processing, the seasonal nature of transport activity, as well as the uneven performance of freights during the different periods of the year. These factors suggest the necessity for recruiting extra personnel.

\section{Trends in Western Europe: trial \& training days and recruitment via business networks}

Staff recruitment for transport organizations is primarily carried out through higher education institutions, industrial schools and specialized schools. In recent years, however, it has been carried

\footnotetext{
${ }^{1}$ Postgraduate, University of National and World Economy "Economics of Transport and Energy" Department, Sofia, Bulgaria.tsonkova.asya@gmail.com
} 
out primarily through the "LinkedIn" online platform for Europe and through "Xing" just for Western Europe. Private companies supplying and demanding employees have also become popular in recent years. There is a tendency for multiple firms and enterprises from Western Europe to turn to mediator firms with the purpose of finding the best suited candidate for the respective job.

In Germany for example more than $50 \%$ of all companies use new internet platforms and social career networks for recruiting (ICR Recruiting Trends, 2017).

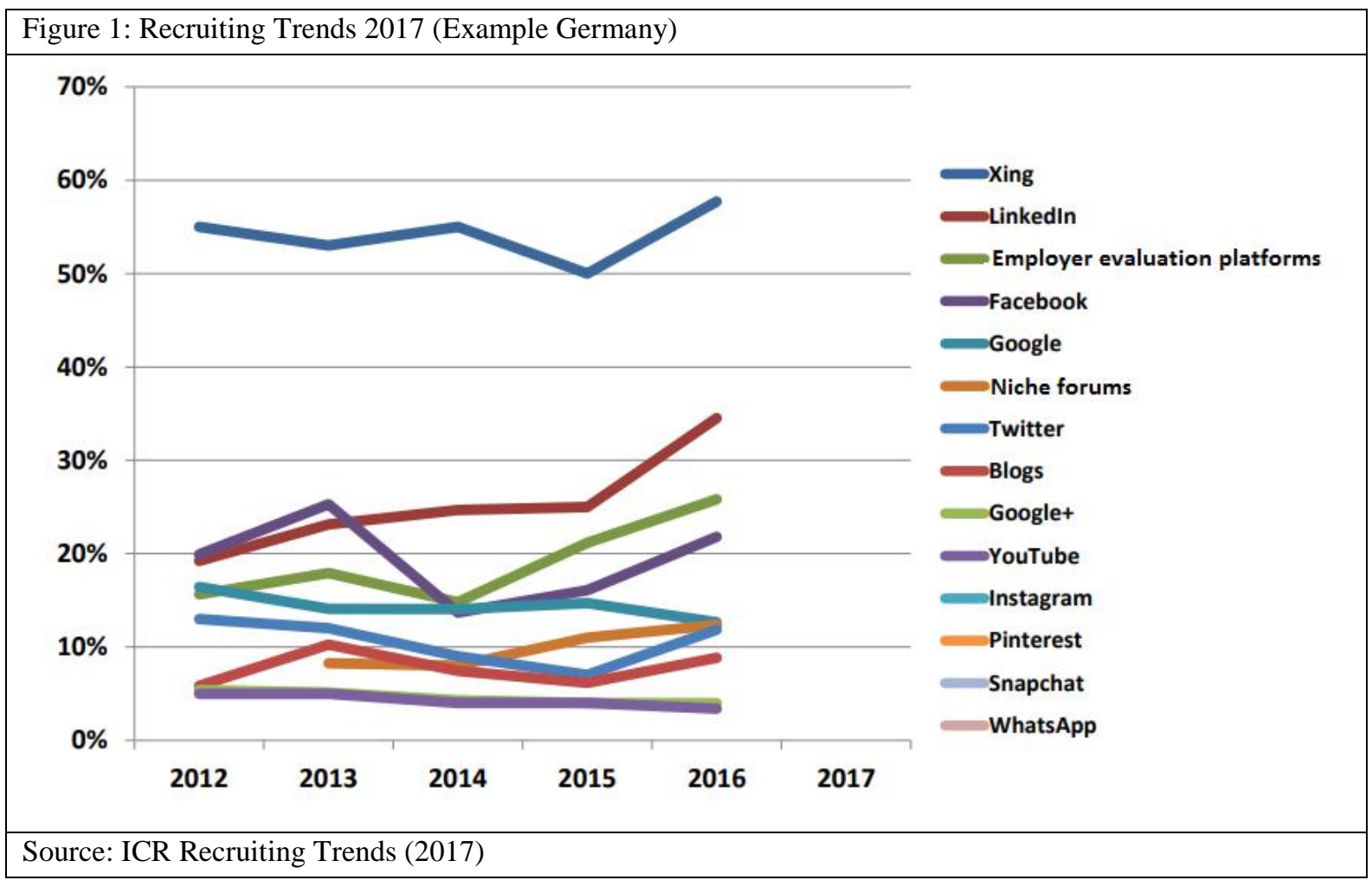

Transport enterprises use primarily psychological tests and interviews in their staff recruitment; for Western Europe this is "Trial Day," which has become a commonly accepted practice. All potentially new employees have to spend 1 to 3 trial days in the company or enterprise, where they observe how the work day goes and they are usually given a task, followed by an evaluation of both the candidate's performance as well as their ability to adapt in the collective and work atmosphere typical of the job specifics and the respective position. During their work, each employee receives a certain amount of training, seminars and specialization; in Western Europe there is also a practice of providing 5 extra days of leave for this type of training, financed by the employer.

It should also be noted that in recent years transport company managers, in addition to traditional methods (lectures, seminars and practice), have employed other modern active methods such as organizing various business role-playing games, managerial situations and tests. The preferred method of managerial training staff is staff rotation. It involves temporary switching of managerial places horizontally in the transport firm's structure, without changing rewards and occupations for a certain period of time. This provides an opportunity for gaining knowledge and experience in the company's various fields, as well as for interacting with other sections and the people working there (Tzvetkova, 2016a).

The main task of the experts from the human resources department in the transport enterprise is the constant improvement and development of staff qualification and skills. For this purpose, a "Personal Development Plan for Employees" is drawn for every new employee during their first year of assuming office. Through this plan, the respective workers are given an opportunity to grow and increase their qualification, which leads to achieving better results as well as capability for taking additional tasks. This can have a positive influence on staff fluctuation and preserve transport companies' professional potential. 
A primary issue in transport activity is the "physical" and "moral" aging of workers. With "moral" aging individual experts and managers cannot use the new methods and innovations in management processes in their work. This also reduces the professional qualities of these managers, which in turn has a negative impact on the effectiveness of the managerial decisions they make (Tzvetkova, 2016b).

There are also other reasons for staff fluctuation in transport enterprises, such as motivation for work or shortage of qualified workers. It is often observed that well trained and capable experts lose their motivation to work due to inadequate pay and lack of a clear strategy for their professional and personal growth. The lack of motivation among workers can also lead to an unsatisfactory level of the quality of transport services.

A large portion of transport firms from Western Europe strive to compensate this type of situation in daily routines by providing employees with other types of stimuli such as: free public transport cards, food coupons, office cars, office phones, tablets, fitness cards, organizing field trips for employees or training employees to acquire specific knowledge and increase their qualification.

\section{Brand management and working conditions influence the level of satisfaction}

Recently, the "Brand Management" position has also been opened in the management of medium and larger European transport firms that have over 500 employees. The primary task of these experts is to focus their efforts on improving the company's image, attract new workers and monitor the level of their satisfaction (PricewaterhouseCoopers, 2012). They have to hold regular polls and conversations with workers and analyse their attitudes regarding the work specifics and atmosphere, acknowledge their desires and level of satisfaction, and make offers for optimizing their work process and improving working conditions and breaks - i.e. flexible work time, "home office", potential for creating commodities at the work place, etc. The function of brand managers is to initiate various campaigns for employees in order to strengthen their mental and physical health.

\begin{tabular}{|l|c|c|}
\hline Figure 2: Tips for employee retention & $\begin{array}{r}\text { Support } \\
\text { personal } \\
\text { development } \\
\text { conditions }\end{array}$ & $\begin{array}{c}\text { Make working } \\
\text { days more } \\
\text { attractive }\end{array}$ \\
\hline $\begin{array}{c}\text { Improve } \\
\text { working } \\
\text { atmosphere }\end{array}$ & $\begin{array}{c}\text { Regular } \\
\text { feedback for } \\
\text { employees }\end{array}$ \\
\hline Sive benefits \\
for \\
performance
\end{tabular}

It should be mentioned that, aside from having a negative influence on the transport enterprise, staff fluctuation can also be a criterion for effectiveness that can improve the quality of human resources because it selects a large number of candidates for the respective period, thus displaying new experience and knowledge. Fluctuation is the cost of replacing leaving employees, but it is also a loss of productivity due to the lack of work force that can take over the increased work load. The reduced productivity, for its part, can reflect on corporate revenues (Tzvetkova, 2016b).

Employers often assume that the employees they have already trained will prefer at any time to work in another company because of a more attractive position or better pay, which often causes tension and discontent in the company. At the same time, however, providing an opportunity for additional training or specialization reduces the risk of staff dissatisfaction and discontent. Based on analyses carried out in Great Britain, it has been determined that employees that have had 5 or more days for training and specialization during the previous year are significantly more loyal to their employers than the ones who have been trained for less than five days. In other words, training provided by employers has a positive effect on staff motivation and improves the working climate based on the 
employees' psychological assumption that their employers understand and care about the people working for them.

Staff fluctuation has economic and social functions. The economic function is represented through the redistribution of the work force between companies and the national economy's branches, the state's regions, the professional and qualification groups in production and managerial personnel. As for the social function, changing the place of employment allows people to satisfy certain needs, to increase their pay, to improve their working conditions, to use social privileges and additional opportunities for professional growth (Tzvetkova, 2016b).

When fluctuation varies between 3-5\% of the company's staff, it is natural and no specific or special measures by the company's management need are necessary. It is important to stress that it is possible to have additional fluctuation that creates production, organization, staff and technical obstacles for the firm's normal functioning.

Staff management plays a leading role in the development of every country because it influences the growth of public production. From the preceding analysis, it can be concluded that staff management in transport enterprises is a combination of principles and requirements for forming and using human resources in the organization in accordance to its interests and goals. Staff fluctuation itself is part of staff management and a primary criterion for evaluating the effectiveness of human resources management. Staff fluctuation is a real indicator for the quality of work life in transport enterprises. In the modern conditions of active market competition and dynamically changing markets where employers compete among themselves for recruiting and keeping better workers, the real risk of fluctuation is an indispensable part of the work process.

\section{Quality staff management plays a role in the national economy}

Management itself constantly develops and stimulates workers' creative initiatives and creates conditions for provoking their activity. The primary goal of every transport enterprise should be the creation of a successful and functioning monitoring and active control over fluctuation. The transport sector, as an attractive and dynamic sector, starts to experience an increasingly stronger shortage of highly qualified experts in the field of transport and logistics who are fluent in several languages and work with the new and optimized programs of the so-called "cloud technology." It is necessary to specify a strategy for the development of human resources, since it will help form a new vision for the development of the transport sector and it will be able to read the specific differences of each subsector.

Modern transport firms in Bulgaria face numerous difficulties and challenges on a daily basis. Quality staff management plays a key role both for the transport firm itself and national economy. For every successful production activity, the management and use of human resources has primary significance, thus creating new value in the production process. Through human resources, the effective activity of transport enterprises is increased substantially, which is why staff management has its leading position.

The state of the labour market also influences staff management. This influence is shown primarily through market mechanisms - supply and demand of work force and intensifying competition. Larger supply and smaller demand for a work force stimulates the motivation for work and improves discipline. Although the size of the companies influences staff management primarily through the mechanisms for carrying out managerial activities, the state also plays a key role in management through national legislation and the adopted international norms. However, the effective management of human resources is what plays a key role in the successful development, prosperity and increased competitiveness of every transport enterprise.

\section{Conclusion}

The human factor plays an increasingly significant and defining role in regard to the development and success of every modern company. Hire the right people and motivate them to do their best and work more efficiently is a key factor of success.

Business in Bulgaria has improved the personal management in recent years to reduce fluctuation.

Coming from Western Europe there is a trend to hire high qualified people via business networks like LinkedIn and install trial \& training days for new employees. Also, a "Personal Development Plan for 
Employees" in combination with giving them a chance to increase their qualification (sponsored by the company) helps to improve moral motivation and to be more loyal. This helps to reduce fluctuation.

To keep well trained employees motivated, payment and company strategy are important. Quality brand management and working conditions influences level of satisfaction. Quality staff management plays a role not only in the transport companies itself but also in national economy.

\section{References}

Armstrong, M. (2006). A Handbook of Human Resource Management Practice, $10^{\text {th }}$ Edition

ICR Recruiting Trends (2017). Retrieved 01/2017 from https://www.competitiverecruiting.de/ICR-Recruiting-Trends-2017datenbasiert-2012-2013-2014-2015-2016.html\#.WZX8IlVJaUl

PricewaterhouseCoopers (PwC) (2012). Transportation \& Logistics 2030 - Volume 5 : Winning the talent race. Retrieved 03/2013 from https://www.pwc.com/gx/en/transportation-logistics/pdf/pwc-tl-2030-volume-5.pdf

Kerneder A. (2016). Mitarbeiterbindung: 10 Tipps für weniger Fluktuation. Retrieved 08/2017 from https://zweikern.com/blog/mitarbeiterbindung

Tzvetkova S. (2015). Управление на текучество на персонала в транспортното предприятие

[The Main Directions in the Development and Management of Human Resources in Transport], electronic journal for "Railway Intermodal Transport", Sofia, issue 8.

Tzvetkova, S. (2016a) "Specific Features of Staff Management in Transport Enterprises", Publ. UNWE, Sofia

Tzvetkova, S. (2016b) Основни насоки в развитието и управлението на човешките ресурси в транспорта [Management of Staff Fluctuation in Transport Enterprises], electronic journal for "Railway Intermodal Transport”, Sofia, issue 9. 